\title{
Measurement of professional performance: statesmanship, entrepreneurship and innovation
}

\author{
Ratnawati Susanto ${ }^{1}$, Harlinda Syofyan ${ }^{1}$ and Reza Rachmadtullah ${ }^{2}$ \\ \{*ratnawati@esaunggul.ac.id\} \\ ${ }^{1}$ Universitas Esa Unggul, Jakarta. Indonesia \\ ${ }^{2}$ Universitas PGRI Adi Buana, Surabaya Indonesia
}

\begin{abstract}
This study aims to obtain measurement data on professional performance with revolutionary 4.0 era skills which include statesmanship, entrepreneurship and innovation dimensions based on Johari Window. The results of the research are the basis for strengthening the capacity and capability of lecturers and Institutes of Teacher's Education (Lembaga Pendidikan dan Tenaga Keguruan or LPTK) and for the development of professional performance models. The sampling technique is saturated with the population of Institutes of Teacher's Education lecturers in 2 universities with A and B accreditation status totaling 105. Quantitative research using survey methods and using a standard questionnaire instrument developed by George Manning \& Kent Curtis on a semantic differential scale. Data processing techniques use frequency distribution and performance pyramid profiles. The results show that professional performance profiles are reflected in statesmanship, entrepreneurship and innovation with significant differences from university accreditation status.
\end{abstract}

Keywords : statesmanship, entrepreneurship and innovation

\section{Introduction}

Data shows that 415 Institutes of Teacher's Education (LPTK) consisting of 37 State Institutes of Teacher's Education and 378 Private LPTKs are considered not yet standard in producing qualified and professional teacher candidates with a level of contribution to student learning outcomes of 50\% [1]. The professional performance of lecturers is a central point in organizational reform [2] Indicators of predictors of professional performance of lecturers are positively and significantly constructed through motivational, competency and leadership factors [3], motivation and discipline [4] , pedagogical factors, personality professional and social competence [5] and assessments of competencies [6].

Professional performance of lecturers through the Tridharma of Higher Education has shown high ability [7]. Recommendations for research on the professional performance of revolutionary 4.0 must be based on innovation. [8] and managerial ability [9] on an ongoing basis [10] .. Especially in the organization of knowledge and skills. [11]. The ability of 
innovation relates to the power to achieve results (entrepreneurship).[12] . Innovation and entrepreneurship desperately need social support. The need to get social support begins with the ability to work and with others (Statesmanship) [13]. Social support is the basis for synergy towards professional performance [14].. Professional performance needs to be measured fundamentally through the understanding of oneself and others (Johari Window) so as to enable a performance assessment to synergize the process of learning from within and transformative with others [15].

\section{Literature Review}

\subsection{Professional performance}

Professionalism is a form of consequences that must be possessed by each individual in the work organization in the face of rapid changes. [16] and as a practical and real form in dealing with these conditions [16] The manifestation of professionalism is performance as accountability that is evaluated through measurement based on teacher performance, program and education. [17] with regard to ethics [18], emotional intelligence factors as theoretical and practical constructs that influence the minimum level of stress leading to stable professional performance[19]. Professional performance needs to be measured using exploratory assessments [19] covers the performance of the revolutionary era 4.0 in 3 areas of statesmanship, entrepreneurship and innovation. [20] The performance pyramid is described as follows.

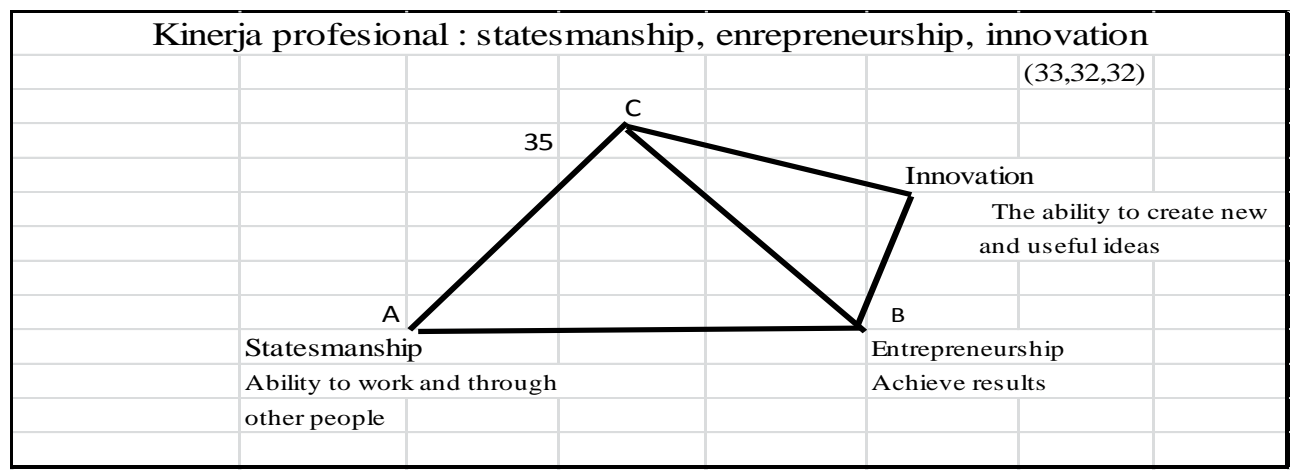

Figure 1. Performance Pyramid

\subsection{Statesmanship}

Statesmen characterize relationships.[21], which underlies moral choices in behaviour[22]. Statesmanship reflects culture, namely the ability to accept and relate to perspective and intuition, Berlin being a strategy in conversation with others [23] and become part of pedagogic abilities [24]. Conceptually statehood is the ability to work with and use other people and produce multiple targets, by type: seeking ideas and connecting others, connecting themselves to help others, seeking consensus in disputes, having very high ability to work with other people and use other people in the process that gives a big influence.

\subsection{Entrepreneurship}


Entrepreneurship as an individual who has the advantage and ability to create value by innovating.[25] Entrepreneurship is an important aspect in structuring a research-oriented university as a university tridharma.[26] . Conceptually entrepreneurship is the ability to achieve results and efforts related to important and fundamental things, with characteristics: being the leading people in achievement, some of the work done has replaced the big, but still trying even though risk, work according to planning and always be able to find ways of doing work [20]

\subsection{Innovation}

Innovation and entrepreneurship are two key capabilities that cannot be separated, and are needed to make the organization grow to a large scale.[27] . Making organizations grow to a large scale requires individual organizations who have the ability to manage change in education. This means that educated leaders are required to be able to innovate.[28] . Conceptually, innovation is the ability to produce novelty and ideas that are useful and keep moving and developing dynamically and not statically, fulfilling the characteristics of always looking for the best way to do things, changing the whole approach to work, always having creativity, ideas what is rolled out is always used, innovative in ideas and work approaches.

\subsection{Johari Window Concept: Self Evaluation and Workers}

Johari Window becomes a model to train self-awareness of individual capacity [29] so that with and through it leads to the development of organizational capacity.[30] . Johari Window becomes important to be used in the framework of capacity building for LPTKs based on experience and self-understanding (what is known) and co-workers' assessment (what others know) towards the process of generating new ideas and actions [31] .

\section{Method}

\subsection{Research Subjects}

The research subjects were private lecturers in 2 LPTKs in DKI Jakarta Province, with A and $\mathrm{B}$ accreditation status. The population was 105 people, consisting of 80 lecturers at universities with accreditation status A and 25 lecturers at universities with accreditation status B. Using sampling techniques saturated, that is, all members of the population are used as samples [32]

\subsection{Data analysis procedures}

This research is a quantitative research with survey method. The data collection used a standard questionnaire instrument developed by George Manning \& Kent Curtis on a semantic differential scale. The guidelines for data interpretation use: (a) score $\leq 14$ (very low), (b) score 15-19 (low), (c) score 20 - 29 (moderate), (d) score 30 - 35 (high). Research respondents were lecturers with self-evaluation techniques and peer assessment. The problem formulation includes: 1. Profile of professional performance of lecturers at A and B accredited universities in the statesmanship, entrepreneurship and innovation dimensions, and (2) differences in professional performance profiles. Processing and presenting data uses: (a) Frequency distribution with centralized data, which includes mean, median, mode, (b) Profile is described in the form of performance pyramid 


\section{Results and Discussion}

Profile of professional performance of lecturers at universities with A and B accreditation status

\subsection{Dimensions of Statesmanship}

Table 1. Frequency Distribution of Statesmanship Dimensions

\begin{tabular}{|c|c|c|c|c|c|c|c|c|c|c|c|c|c|}
\hline \multicolumn{14}{|c|}{ Statistics } \\
\hline & & $\begin{array}{l}\text { the search for } \\
\text { ideas and } \\
\text { opinions of } \\
\text { others (A) }\end{array}$ & \begin{tabular}{|l|} 
out of the way \\
of working to \\
help others \\
(A)
\end{tabular} & $\begin{array}{c}\text { consensus in } \\
\text { resolving } \\
\text { disputes (A) }\end{array}$ & $\begin{array}{l}\text { the ability to work } \\
\text { with others and } \\
\text { (A) }\end{array}$ & \begin{tabular}{|c|} 
inwolving people \\
others in \\
making very \\
basic \\
decisions.(A) \\
\end{tabular} & \begin{tabular}{|c|} 
the search for \\
ideas and \\
opinions of \\
others (B)
\end{tabular} & \begin{tabular}{|c|} 
out of the way \\
of working to \\
help others (B)
\end{tabular} & $\begin{array}{c}\text { consensus in } \\
\text { resolving } \\
\text { disputes (B) }\end{array}$ & \begin{tabular}{|c|} 
the ability to \\
work with \\
others and (B) \\
\end{tabular} & \begin{tabular}{|c|} 
involving \\
people others \\
in making \\
very basic \\
decisions.(B)
\end{tabular} & $\begin{array}{c}\text { STATESMANSHIP } \\
\text { ACCREDITATION } \\
\text { LECTURERS B } \\
\end{array}$ & \begin{tabular}{|c|} 
STATESMANSHIP \\
ACCREDITATION \\
LECTURERS A
\end{tabular} \\
\hline \multirow[t]{2}{*}{$\mathrm{N}$} & Valid & 80 & 80 & 80 & 80 & 80 & 25 & 25 & 25 & 25 & 25 & 25 & 80 \\
\hline & Missing & 80 & 80 & 80 & 80 & 80 & 135 & 135 & 135 & 135 & 135 & 135 & 80 \\
\hline \multicolumn{2}{|c|}{ Mean } & 5.20 & 5.48 & 5.08 & 6.33 & 5.38 & 3.96 & 3.00 & 4.12 & 4.76 & 4.44 & 4.06 & 5.49 \\
\hline \multicolumn{2}{|c|}{ Median } & 5.00 & 5.00 & 5.00 & 7.00 & 5.00 & 3.00 & 3.00 & 5.00 & 5.00 & 5.00 & 4.20 & 5.40 \\
\hline \multicolumn{2}{|c|}{ Mode } & 5 & 5 & 5 & 7 & 5 & 3 & 3.0 & 5 & 5 & 5 & 4.20 & 5.40 \\
\hline \multicolumn{2}{|c|}{ Minimum } & 3 & 3 & 3 & 3 & 5 & 3 & 3.0 & 3 & 3 & 3 & 3.40 & 4.20 \\
\hline \multicolumn{2}{|c|}{ Maximum } & 7 & 7 & 7 & 7 & 7 & 7 & 3.0 & 5 & 7 & 7 & 5.40 & 7.00 \\
\hline \multicolumn{2}{|c|}{ Sum } & 416 & 438 & 406 & 506 & 430 & 99 & 75.0 & 103 & 119 & 111 & 101.40 & 439.20 \\
\hline
\end{tabular}

The profile of the professional performance of the lecturer in the statesmanship dimension is measured by indicators (a) the search for ideas and opinions of others (b) out of the way of working to help others (c) consensus in resolving disputes (d) the ability to work with others and (e) involving people others in making very basic decisions. The profile of professional performance on the statesmanship dimension of lecturers at A-accredited universities is at a score of 33 from the ideal score of 35 . And a score of 24 for lecturers at universities with B accreditation. This puts the level of professional performance in the statesmanship dimension of lecturers at universities with $\mathrm{A}$ accreditation high professional and at university $\mathrm{B}$ on moderate professional performance.

\subsection{Dimensional entrepreneurship}

The performance profile of the lecturer on the dimensions of entrepreneurship is measured by the indicators (a) the top achievement (b) the work always contributes greatly, (c) takes the opportunity even though at risk, (d) works according to planning, and (e) always finds ways to solve everything thing Professional performance profiles on the dimensions of entrepreneurship lecturers at A-accredited universities are at a score of 32 of 35 ideal scores and a score of 25 is achieved by lecturers at B. accredited universities. at university B on moderate professional performance

Table 2. Frequency Distribution of Entrepreneurship Dimensions 


\begin{tabular}{|c|c|c|c|c|c|c|c|c|c|c|c|c|c|}
\hline \multicolumn{14}{|c|}{ Statistics } \\
\hline & & \begin{tabular}{|c|} 
ENTREPRENEUR \\
SHIP \\
ACCREDITATIO \\
N LECTUREA
\end{tabular} & $\begin{array}{c}\text { the top } \\
\text { achievement } \\
\text { (A) }\end{array}$ & $\begin{array}{l}\text { the work } \\
\text { always } \\
\text { contributes } \\
\text { greatly (A) }\end{array}$ & \begin{tabular}{|c|} 
takes the \\
opportunity even \\
though at risk (A)
\end{tabular} & \begin{tabular}{|c|} 
works according \\
to planning (A)
\end{tabular} & $\begin{array}{l}\text { always finds } \\
\text { ways to solve } \\
\text { everything } \\
\text { thing (A) }\end{array}$ & $\begin{array}{c}\text { ENTREPRENEUR } \\
\text { SHIP } \\
\text { ACCREDITATIO } \\
\text { NLECTUREB }\end{array}$ & $\begin{array}{l}\text { the top } \\
\text { achievement } \\
\text { (B) }\end{array}$ & $\begin{array}{l}\text { the work } \\
\text { always } \\
\text { contributes } \\
\text { greatly (B) }\end{array}$ & \begin{tabular}{|c|} 
takes the \\
opportunity \\
even though \\
at risk (B)
\end{tabular} & $\begin{array}{c}\text { works according } \\
\text { to planning (B) }\end{array}$ & $\begin{array}{c}\text { always finds } \\
\text { ways to solve } \\
\text { everything } \\
\text { thing (B) }\end{array}$ \\
\hline \multirow[t]{2}{*}{ N } & Valid & 80 & 80 & 80 & 80 & 80 & 80 & 25 & 25 & 25 & 25 & 25 & 25 \\
\hline & Missing & 80 & 80 & 80 & 80 & 80 & 80 & 135 & 135 & 135 & 135 & 135 & 135 \\
\hline \multicolumn{2}{|c|}{ Mean } & 5.33 & 4.90 & 5.45 & 5.05 & 5.93 & 5.33 & 4.25 & 4.12 & 3.56 & 4.20 & 4.92 & 4.44 \\
\hline \multicolumn{2}{|c|}{ Median } & 5.40 & 5.00 & 5.00 & 5.00 & 7.00 & 5.00 & 4.20 & 3.00 & 3.00 & 5.00 & 5.00 & 5.00 \\
\hline \multicolumn{2}{|c|}{ Mode } & 5.40 & 5 & 5 & 5 & 7 & 5 & 3.80 & 3 & 3 & 5 & 5 & 5 \\
\hline \multicolumn{2}{|c|}{ Minimum } & 4.20 & 3 & 3 & 3 & 3 & 5 & 3.80 & 3 & 3 & 3 & 3 & 3 \\
\hline \multicolumn{2}{|c|}{ Maximum } & 7.00 & 7 & 7 & 7 & 7 & 7 & 5.40 & 7 & 5 & 5 & 7 & 7 \\
\hline \multicolumn{2}{|c|}{ Sum } & 426 & 392 & 436 & 404 & 474 & 426 & 106.20 & 103 & 89 & 105 & 123 & 111 \\
\hline
\end{tabular}

4.3. Innovative dimensions

Table 3. Frequency Distribution of Innovative Dimensions

\begin{tabular}{|c|c|c|c|c|c|c|c|c|c|c|c|c|c|}
\hline \multicolumn{14}{|c|}{ Statistics } \\
\hline & & \begin{tabular}{|c|} 
NNOVATION \\
ACCREDITATION \\
LECTURERS A
\end{tabular} & $\begin{array}{l}\text { looking for } \\
\text { better ways } \\
\text { (A) }\end{array}$ & \begin{tabular}{|c|} 
changing \\
approaches to \\
work (A)
\end{tabular} & $\begin{array}{c}\text { famous for } \\
\text { creativity (A) }\end{array}$ & $\begin{array}{l}\text { ideas are almost } \\
\text { always used (A) }\end{array}$ & $\begin{array}{c}\text { innovative in } \\
\text { ideas and } \\
\text { working } \\
\text { approaches (A) }\end{array}$ & $\begin{array}{c}\text { INNOVATION } \\
\text { ACCREDITATION } \\
\text { LECTURERS A }\end{array}$ & $\begin{array}{l}\text { looking for } \\
\text { better ways } \\
\text { (B) }\end{array}$ & $\begin{array}{c}\text { changing } \\
\text { approaches to } \\
\text { work (B) }\end{array}$ & \begin{tabular}{|c|} 
famous for \\
creativity (B)
\end{tabular} & \begin{tabular}{|l|} 
ideas are almost \\
always used(B)
\end{tabular} & $\begin{array}{l}\text { innovative in } \\
\text { ideas and } \\
\text { working } \\
\text { approaches } \\
\text { (B) } \\
\end{array}$ \\
\hline \multirow[t]{2}{*}{$\mathbf{N}$} & Valid & 80 & 80 & 80 & 80 & 80 & 80 & 25 & 25 & 25 & 25 & 25 & 25 \\
\hline & Missing & 80 & 80 & 80 & 80 & 80 & 80 & 135 & 135 & 135 & 135 & 135 & 135 \\
\hline \multicolumn{2}{|c|}{ Mean } & 5.28 & 5.33 & 5.10 & 4.58 & 6.15 & 5.23 & 4.26 & 4.68 & 4.04 & 4.04 & 4.44 & 4.12 \\
\hline \multicolumn{2}{|c|}{ Median } & 5.40 & 5.00 & 5.00 & 5.00 & 7.00 & 5.00 & 4.20 & 5.00 & 5.00 & 5.00 & 5.00 & 5.00 \\
\hline \multicolumn{2}{|c|}{ Mode } & $5,00^{\mathrm{a}}$ & 5 & 5 & 5 & 7 & 5 & 3.80 & 5 & 5 & 5 & 3 & $3^{\mathrm{a}}$ \\
\hline \multicolumn{2}{|c|}{ Minimum } & 4.20 & 3 & 3 & 3 & 3 & 5 & 3.80 & 3 & 3 & 3 & 3 & 3 \\
\hline \multicolumn{2}{|c|}{ Maximum } & 6.60 & 7 & 7 & 7 & 7 & 7 & 5.40 & 7 & 5 & 5 & 7 & 7 \\
\hline \multicolumn{2}{|c|}{ Sum } & 422 & 426 & 408 & 366 & 492 & 418 & 106.60 & 117 & 101 & 101 & 111 & 103 \\
\hline
\end{tabular}

Lecturer performance profiles in the innovative dimensions are measured by indicators (a) looking for better ways (b) changing approaches to work, (c) famous for creativity, (d) ideas are almost always used and (e) innovative in ideas and working approaches. Profile of professional performance on innovative dimensions A accredited university lecturers are on score 32 of 35 ideal scores and score 26 is obtained by lecturers at universities with B accreditation status. This puts the level of professional performance quality in innovative dimensions lecturers at A-accredited universities are high professional and at university $\mathrm{B}$ on moderate professional performance.

\subsection{Differences in the profile of lecturers' professional performance at the $A$ and $B$ accreditation status}

Table 4. Professional Performance Frequency Distribution 


\begin{tabular}{|c|c|c|c|c|c|c|c|}
\hline \multicolumn{8}{|c|}{ Statistics } \\
\hline & & \begin{tabular}{|c|} 
STATESMANSHIP \\
ACCREDITATION \\
LECTURERS A
\end{tabular} & \begin{tabular}{|c|} 
ENTREPRENEURSHIP \\
ACCREDITATION \\
LECTUREA
\end{tabular} & \begin{tabular}{|c|} 
INNOVATION \\
ACCREDITATION \\
LECTURERS A \\
\end{tabular} & $\begin{array}{l}\text { STATESMANSHIP } \\
\text { ACCREDITATION } \\
\text { LECTURERS B }\end{array}$ & $\begin{array}{c}\text { ENTREPRENEURSHIP } \\
\text { ACCREDITATION } \\
\text { LECTURE B }\end{array}$ & $\begin{array}{c}\text { INNOVATION } \\
\text { ACCREDITATION } \\
\text { LECTURERS A }\end{array}$ \\
\hline \multirow[t]{2}{*}{$\mathbf{N}$} & Valid & 80 & 80 & 80 & 25 & 25 & 25 \\
\hline & Missing & 80 & 80 & 80 & 135 & 135 & 135 \\
\hline \multicolumn{2}{|c|}{ Mean } & 5.49 & 5.33 & 5.28 & 4.06 & 4.25 & 4.26 \\
\hline \multicolumn{2}{|c|}{ Median } & 5.40 & 5.40 & 5.40 & 4.20 & 4.20 & 4.20 \\
\hline \multicolumn{2}{|c|}{ Mode } & 5.40 & 5.40 & $5,00^{\mathrm{a}}$ & 4.20 & 3.80 & 3.80 \\
\hline \multicolumn{2}{|c|}{ Minimum } & 4.20 & 4.20 & 4.20 & 3.40 & 3.80 & 3.80 \\
\hline \multicolumn{2}{|c|}{ Maximum } & 7.00 & 7.00 & 6.60 & 5.40 & 5.40 & 5.40 \\
\hline \multicolumn{2}{|c|}{ Sum } & 439.20 & 426.40 & 422.00 & 101.40 & 106.20 & 106.60 \\
\hline
\end{tabular}

a. Multiple modes exist. The smallest value is shown

The profile of the professional performance of lecturers in the status of A and B accreditation has a significant difference. The profile of professional performance of lecturers at Aaccredited universities is a high level of professional performance, both in the statesmanship dimension (score 33 or 94\%), dimensions of entrepreneurship (score 32 or 91\%) and on dimensions of innovation (score 32 or $91 \%$ ). While the profile of professional performance of lecturers at B-accredited universities is at the level of moderate professional performance, both in the statesmanship dimension (score 24 or achievement of $69 \%$ quality), dimensions of entrepreneurship (score 25 or $71 \%$ ), and dimensions of innovation (score 26 or $74 \%$ ). Therefore it can be stated that there are differences in the professional performance profiles of lecturers who are at A universities and B universities.

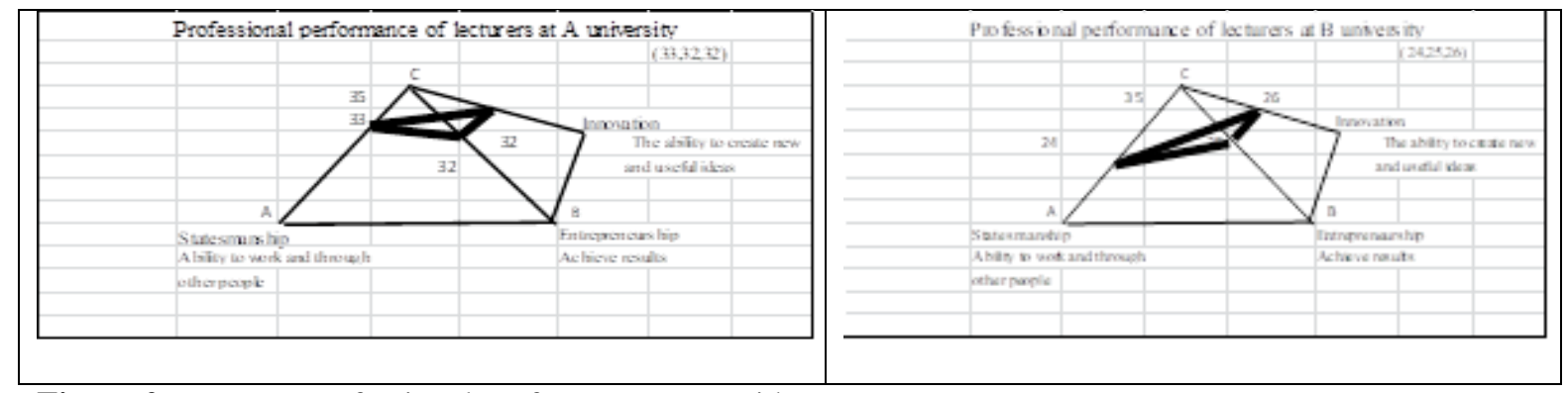

Figure 2. Lecturer Professional Performance Pyramid

\section{Conclusion}

a. Lecturers at A-accredited universities have statesmanship profiles with high standards which indicate having the ability to work with and through others to produce multiple goals. Likewise, lecturers at B-accredited universities also have quite good (moderate) statesmanship profiles. It can be stated that the lecturers individually, groups and organizations are prepared and can work together and work together to improve the capacity and capability of the Institutes of Teacher's Education.

b. Lecturers at a meditation university A have a high entrepreneurship profile, which signifies the ability to achieve a result and dismiss existing barriers by being oriented to action and achievement as important and fundamental. Likewise with lecturers at Baccredited universities who also have a fairly good (moderate) profile of 
entrepreneurship. It can be stated that the lecturers have the ability to achieve the planned results to increase the capacity and capability of the Institutes of Teacher's Education.

c. Lecturers at A-cited University have a high innovation profile, which signifies the ability to produce novelty and ideas that are useful and keep moving and developing dynamically and not statically. Likewise with lecturers at B-accredited universities who also have a fairly good (moderate) innovation profile. It can be stated that the lecturers can produce new plans and strategies in an effort to increase the capacity and capability of the Institutes of Teacher's Education

d. There are differences in the professional performance profiles of the lecturers. Lecturers at A-accredited universities are at a higher level of quality compared to lecturers at B. accredited universities.

\section{References}

[1] Kemenristekdikti, Pedoman, Pembukaan Program Studi Pendidikan Profesi Guru di Lembaga Pendidikan Tenaga Kependidikan. Jakarta, 2007.

[2] S. Suryaman, "Indonesian Private University Lecturer Performance Improvement Model to Improve a Sustainable Organization Performance," Int. J. High. Educ., vol. 7, no. 1, p. 59, 2018.

[3] A. Pramudyo, “Analisis Faktor-Faktor Yang Mempengaruhi Kinerja Dosen Negeri Pada Kopertis Wilayah V Yogyakarta," Jbti, vol. 1, no. 1, pp. 1-11, 2010.

[4] T. Sulastri, "Hubungan motivasi berprestasi dan disiplin dengan kinerja dosen," $J$. Optim., vol. 1, no. 1, pp. 13-21, 2007.

[5] A. Hakim, "Contribution of Competence Teacher (Pedagogical, Personality, Professional Competence and Social) On the Performance of Learning," Int. J. Eng. Sci., vol. 4, no. 2, pp. 1-12, 2015.

[6] W. Maba, I. Bagus, K. Perdata, and N. Astawa, "Constructing Assessment Instrument Models for Teacher's Performance, Welfare and Education Quality," Int. J. Soc. Sci. Humanit. , vol. 1, no. 3, pp. 88-96, 2017.

[7] R. Susanto, N. Agustina, and R. Gantino, "Lecturers ' Professionality towards PreService Teachers 'Perception and Professional Commitment," ICRI, vol. 1, no. 1, 2018.

[8] R. Susanto, “Analysis Of Lectures ' Profesionality Towards Pre- Service Teachers ' Professional Comitment ( Capacity Building of Teacher Training and Education Faculty )," ICEE, no. 12, 2018.

[9] S. A. \& L. B. Oberg, "Performance in The Wake of New Managerialism," Journals Eur. Polit. Sci. Rev., vol. 2, no. 4, 2014.

[10] C. C. G, Trorey, Professional Development and Institutional Needs, First. London: Routledge, 2017.

[11] N. Fu, P. C. Flood, J. Bosak, T. Morris, and P. O’Reagan, "How do high performance work systems influence organizational innovation in professional service firms," $J$. Empl. Relations, vol. 37, no. 2, pp. 209-231, 2015.

[12] Z. J. Acs and D. B. Audretsch, "Entrepreneurship and Innovation," Discuss. Pap. Entrep. Growth Public Policy, p. 43, 2005.

[13] M. Fauzan, "Peningkatan Kinerja Dosen Berbasis Modal Sosial dan Dukungan Organisasional di PTS Kota Semarang,” J. Bisnis dan Ekon., vol. 19, no. 2, pp. 188$203,2012$. 
[14] S. Chang and J. Shim, "When does transition from family to professional management improve firm performance?," Strateg. Manag. J., vol. 36, no. April, p. 2289, 2014.

[15] et al. M, Marcia , E.D, Mary, "Conceptual Elements for Performance Assesment for Faculty and Student Learning," ICPE, vol. 13, pp. 3-5, 2016.

[16] D. Gleeson and D. Knights, "Challenging Dualism: Public Professionalism in 'Troubled'Times," Sociology, vol. 1, no. 1, 2006.

[17] S. Elam, "Performance Based Teacher Education. What is the State of the Art?," ERIC, vol. $1,1971$.

[18] et al Cameron, Glen T, "Developing standards of professional performance in public relations Developing standards of professional performance in public relations," Public Relat. Rev., vol. 22, no. 1, p. 1996, 1996.

[19] J. R. Barriball, Louise, Joanne Fitzpatrick, "Emotional intelligence : Its relationship to stress , coping, well-being and professional performance in nursing students," Nurse Educ. Today, vol. 31, no. 8, pp. 855-860, 2011.

[20] G. and K. C. Manning, The Art of Leadership. New York: Mc Graw Hill, 2009.

[21] et al Carrese, Paul, Jeffrey Church, Magnanimity and Statesmanship. Lanham, Maryland: Lexington Books, 2008.

[22] A. Wolfers, "Statesmanship and Moral Choice," PIIRS, vol. 1, no. 2, p. 464842, 2011.

[23] G. O. Tuathail and G. Toal, "Problematizing Geopolitics: Survey, Statesmanship and Strategy," Trans. Inst. Br. Geogr., vol. 19, no. 3, p. 259, 1994.

[24] G. S. Hall, "What is Pedagogy?," Pedagog. Semin., vol. 12, no. 4, pp. 375-383, 1905.

[25] W. B. Gartner, "What are we talking about when we talk about entrepreneurship?," ournal Bus. Ventur., vol. 5, no. 90, pp. 15-28, 1990.

[26] S Venkataraman, "The Distinctive Domain of Entrepreneurship Research," Res. Gate, no. January 1997, pp. 1-36, 2011.

[27] D. Johnson, "What is innovation and entrepreneurship? Lessons for large organizations," Ind. Com. Train., vol. 33, no. 4, pp. 135-140, 2001.

[28] D. Mandic, "Managing innovations in education," Recent Adv. Artif. Intell. Knowl. Eng. Data Bases, 2010.

[29] S. Beverly, "Combining Mandala and The JOhari Windoe: An Exercise in Self Awareness," Teachng Learn. Nurs., vol. 2, no. 1, pp. 8-11, 2017.

[30] A. Drejer, "Organisational learning and competence development," Learn. Organ., vol. 7, no. 4, pp. 206-220, 2000.

[31] J. H. and C. S. Barrett, P.S., Is Briefing Innovation? USA: E \& FN SPON, 1996.

[32] 2011, Statistika untuk Pendidikan. Jakarta: Alfabeta. 